\title{
Sew Disease Reports \\ First report of Tobacco leaf curl Cuba virus infecting common bean in Cuba
}

R.M. Leyva ${ }^{1}$, M.L. Quiñones ${ }^{2}$, K.I. Acosta $^{3}$, B. Piñol ${ }^{2}$, C.D. Xavier ${ }^{4}$ and F.M. Zerbini $^{4}$

${ }^{1}$ Unidad de Extensión, Investigación y Capacitación Agropecuaria de Holguín (UEICA-H), Cuba; ${ }^{2}$ Centro Nacional de Sanidad Agropecuaria, Apdo. 10, San José de Las Lajas, 32700, Cuba; ${ }^{3}$ Universidad de Las Tunas, 75200, Las Tunas, Cuba; ${ }^{4}$ Departamento de Fitopatologia/BIOAGRO, Universidade Federal de Viçosa, Viçosa, Minas Gerais, 36570-900, Brasil

*E-mail: madeqp@censa.edu.cu

Received: 05 Apr 2016. Published: 20 Apr 2016. Keywords: begomovirus, emerging pathogen, Phaseolus vulgaris

In Cuba begomoviruses have emerged as one of the major factors limiting production of solanaceous and fabaceous crops. The begomovirus Bean golden yellow mosaic virus affects the major production areas of common bean (Phaseolus vulgaris) in the country (Echemendía et al., 2001). Recently there has been an increase in the range of symptoms in beans, suggesting that other begomoviruses may be present.

During surveys of four fields of common bean in the province of Villa Clara (central Cuba) between November and December 2014, approximately $10 \%$ of plants exhibited begomovirus-like symptoms (Figs. 1,2 ), including yellow mosaic, dwarfing, leaf blistering and abortion of flowers. A total of 23 leaf samples were collected and total DNA was extracted. Conventional PCR using universal primers PaL1v1978/PAR1c496 (Rojas et al., 1993) and rolling circle amplification combined with restriction fragment length polymorphism analyses showed begomoviruses to be associated with $80 \%$ of the symptom-bearing plants.

HindIII fragments of $\sim 2.6 \mathrm{~kb}$ were ligated in the pBluescript $\mathrm{KS}(+)$ plasmid vector, previously cleaved with the same enzyme, and inserts of eight clones (two each from four samples) were sequenced. DNA-A sequences were obtained which shared $99.5 \%$ nucleotide sequence identity. The sequence of one presumed full-length clone (GenBank Accession No. KU562963), comprising 2610 nucleotides, showed the highest nucleotide identity (97\%) with Tobacco leaf curl Cuba virus (TbLCCuV; AM050143) by BLAST analysis. Based on the begomovirus species demarcation criteria (Brown et al., 2015) the virus is an isolate of TbLCCuV.

TbLCCuV has previously been detected in tobacco in Cuba (Morán et al., 2006). Other begomoviruses are known to infect beans including Bean calico mosaic virus, Bean dwarf mosaic virus, Bean golden mosaic virus (Morales, 2011), Soybean blistering mosaic virus and Tomato yellow spot virus (Rodríguez-Pardina et al., 2011). To our knowledge, this is the first report of TbLCCuV infecting common bean.

\section{Acknowledgements}

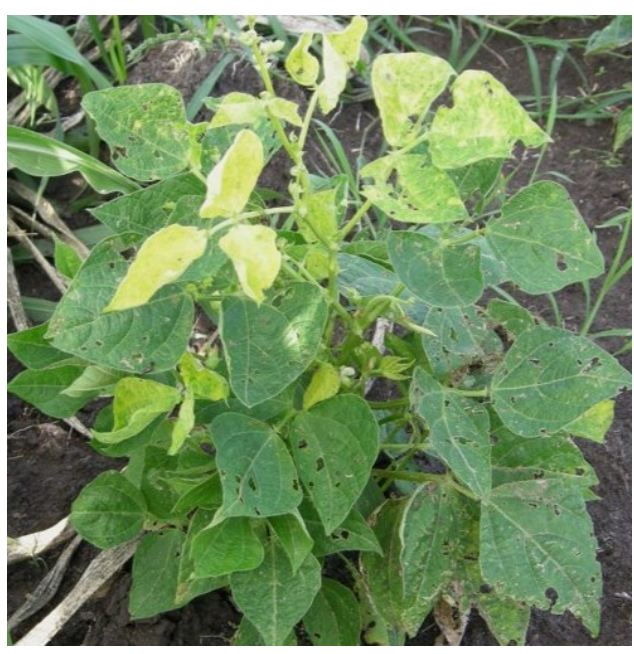

Figure 1
This work was supported by the CAPES-MES grant 155/12.

\section{References}

Brown JK, Zerbini FM, Navas-Castillo J, Moriones E, Ramos-Sobrinho R, Silva JCF, Fiallo-Olivé E, Briddon RW, Hernández-Zepeda C, Idris A, Malathi VG, Martin DP, Rivera-Bustamante R, Ueda S, Varsani A, 2015. Revision of Begomovirus taxonomy based on pairwise sequence comparisons. Archives of Virology 160, 1593-1619.

http://dx.doi.org/10.1007/s00705-015-2398-y

Echemendía AL, Ramos PL, Peral R, Fuentes A, González G, Sanpedro J, Morales FJ, 2001. Cuban isolate of Bean golden yellow mosaic virus is a member of the Mesoamerican BGYMV group. Plant Disease 85, 1030. http://dx.doi.org/10.1094/PDIS.2001.85.9.1030C

Morales FJ, 2011. Interaction between Bemisia tabaci, begomoviruses, and plant species in Latin America and the Caribbean. In: The

Whitefly, Bemisia tabaci (Homoptera: Aleyrodidae) Interaction with Geminivirus-Infected Host Plants. Dordrecht, The Netherlands: Springer, 15-49. http://dx.doi.org/10.1007/978-94-007-1524-0 2

Morán YM, Ramos PL, Domínguez M, Fuentes AD, Sánchez Y, Crespo JÁ, 2006. Tobacco leaf curl Cuba virus, a new begomovirus infecting tobacco (Nicotiana tabacum) in Cuba. Plant Pathology 55, 570. http://dx.doi.org/10.1111/j.1365-3059.2006.01368.x

Rodríguez-Pardina PE, Hanada K, Laguna IG, Zerbini FM, Ducasse DA, 2011. Molecular characterisation and relative incidence of bean- and soybean-infecting begomoviruses in northwestern Argentina. Annals of Applied Biology 158, 69-78.

http://dx.doi.org/10.1111/j.1744-7348.2010.00441.x

Rojas MR, Gilbertson RL, Russell DR, Maxwell DP, 1993. Use of degenerate primers in the polymerase chain reaction to detect whiteflytransmitted geminiviruses. Plant Disease 77, 340-347. http://dx.doi.org/10.1094/PD-77-0340

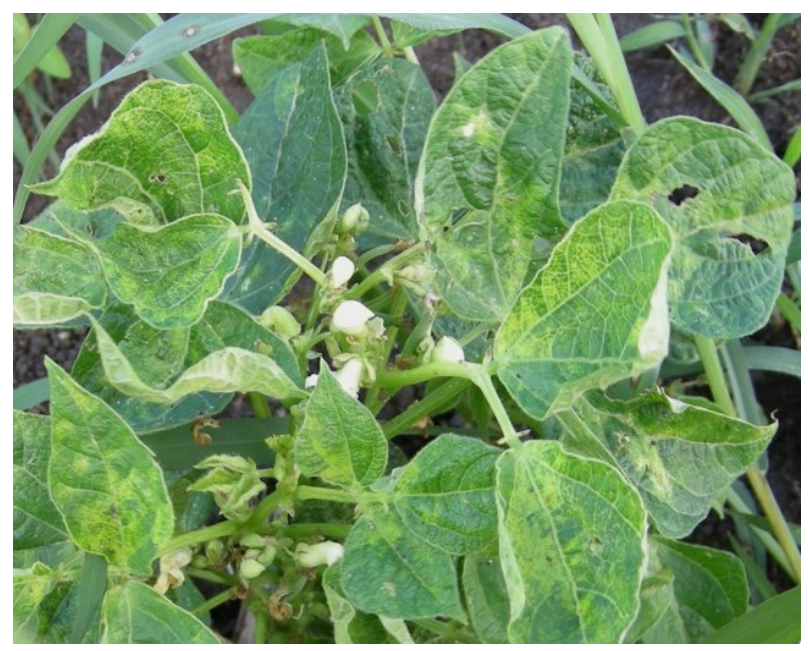

Figure 2

To cite this report: Leyva RM, Quiñones ML, Acosta KI, Piñol B, Xavier CD, Zerbini FM, 2016. First report of Tobacco leaf curl Cuba virus infecting common bean in Cuba. New Disease Reports 33, 17. http://dx.doi.org/10.5197/j.2044-0588.2016.033.017

(c) 2016 The Authors

This report was published on-line at www.ndrs.org.uk where high quality versions of the figures can be found. 